e-ISSN : 2621-4105

\title{
PERLINDUNGAN HUKUM TERHADAP PELANGGAN TV BERBAYAR DITINJAU DARI PERATURAN PEMERINTAH NOMOR 52 TAHUN 2005 TENTANG PENYELENGGARAAN LEMBAGA PENYIARAN BERLANGGANAN MELALUI SATELIT, KABEL DAN TERESTERIAL
}

\author{
Rini Sulistyowati \\ Magister Hukum Universitas Semarang
}

\begin{abstract}
ABSTRAK
Tujuan dari penelitian ini adalah untuk mengetahui dan menganalisa perlindungan hukum terhadap pelanggan TV berbayar ditinjau dari peraturan yang ada. Bergulirnya reformasi semenjak tahun 1998 mendorong bergeraknya informasi kearah kebebasan yang hampir tanpa kendali. Dalam kebebasan berkomunikasi dan hak atas informasi maka pemerintah juga menetapkan Undang-Undang Nomor 32 Tahun 2002 tentang penyiaran. Pertumbuhan penyiaran radio dan televisi baik di kota maupun di daerah semakin meningkat. Berdasarkan Undang-Undang nomor 32 Tahun 2002 tentang Penyiaran dan Peraturan Pemerintah Nomor 52 Tahun 2005 tentang Penyelenggaraan berdasarkan Pancasila dan Undang-Undang Dasar Negara Republik Indonesia Tahun 1945 dengan berdasarkan asas manfaat, adil dan merata, kepastian hukum keamanan, keberagaman, kemitraan adalah bagaimana perlindungan hukum terhadap pelanggan TV berbayar sesuai dengan Peraturan Pemerintah Nomor 52 Tahun 2005. Metode yang digunakan dalam penelitian ini adalah dengan metode yuridis normatif. Hasil penelitian ini pada akhirnya memberi jawaban bahwa bentuk penyiaran berlangganan, khususnya Televisi berlangganan di Indonesia, bila ada penyimpangan harus dicari terlebih dahulu faktor apa yang menyebabkan penyimpangan tersebut sehingga dapat dicari solusinya dan pecegahan sebelum penyimpangan tersebut terulang kembali di kemudian hari, maka di butuhkan pemahaman dan pengetahuan tentang aturan hukum baik dalam menyusun perjanjian kerjasama distributor dan faktor pendorong terjadinya penyimpangan pelaksanaan perjanjian kerjasama, berdasarkan peraturan pemerintah nomor 52 tahun 2005 tentang penyelenggaraan lembaga penyiaran berlangganan melalui satelit, kabel dan teresterial, seperti inkonsistensi antara Pasal yang satu dengan Pasal yang lainnya.
\end{abstract}

Kata Kunci: perlindungan pelanggan; tv berbayar; penyiaran 
$e-I S S N: 2621-4105$

\title{
LEGAL PROTECTION OF CUSTOMIZED TV CUSTOMERS REVIEWED FROM GOVERNMENT REGULATION NUMBER 52 OF 2005 CONCERNING THE OPERATION OF INSTITUTIONAL BROADCASTING BROADCASTING IN SATELLITE, CABLE AND TERRESTERIALS
}

\author{
Rini Sulistyowati \\ Master of Law, University of Semarang
}

\begin{abstract}
The roll of reform since 1998 has encouraged the movement of information towards almost unrestrained freedom, In freedom of communication and the right to information, the government also stipulates Law number 32 of 2002 concrning broadcasting, the growth of radio and television broadcasting in both cities and regions is increasing, Based on Law Number 32 of 2002 concerning Broadcasting and Government Regulation Number 52 of 2005 concerning Implementation based on Pancasila and the 1945 Constitution of the Republic of Indonesia based on the principle of benefit, Fair and Equitable, Legal certainty of security, diversity, partnership is how legal protection for pay TV customers is in accordance with Government Regulation Number 52 of 2005. The method used in this study is a normative juridical method. The results of this study ultimately gave the answer that the form of broadcasting was subscribe, Especially Television subscription in Indonesia, If there are irregularities, what factors have caused the irregularities to be sought so that the solution can be sought and prevented before the irregularities repeat again later on, then it requires understanding and knowledge of the rule of law both in drafting the distributor cooperation agreement and the driving factors for the occurrence of irregularities in the implementation of the cooperation agreement, Based on government regulation number 52 of 2005 concerning the implementation of broadcasting institutions subscribe via satetellete, cable and terrestrial, such as inconsistencies between Article one and other Article.
\end{abstract}

Keywords : Customer protection; tv cable; broadcasting 
e-ISSN : 2621-4105

\section{A. PENDAHULUAN}

Bergulirnya reformasi semenjak tahun 1998 mendorong bergeraknya informasi ke arah kebebasan yang hampir tanpa kendali. ${ }^{1}$ Perkembangan teknologi dan informasi tersebut telah membawa implikasi terhadap dunia penyiaran, termasuk penyiaran di Indonesia. Penyiaran sebagai penyalur informasi dan membentuk pendapat umum. Perannya semakin strategis terutama dalam mengembangkan alam demokrasi dinegara Indonesia, penyiaran telah menjadi salah satu sarana berkomunikasi bagi masyarakat, lembaga penyiaran, dunia bisnis dan pemerintah. ${ }^{2}$ Sehingga kebebasan komunikasi dan memperoleh informasi saat ini telah dijamin oleh pemerintah, sebagimana yang tercantum dalam undangundang dasar negara republik indonesia tahun 1945 pasal 28F menyebutkan, 'setiap orang berhak berkomunikasi dan memperoleh informasi untuk mengembangkan pribadi dan lingkungan sosialnya, serta berhak untuk mencari, memperoleh, memiliki, menyimpan, mengolah dan menyampaikan informasi dengan menggunakan segala jenis saluran yang tersedia.

Dalam menjamin kebebasan berkomunikasi dan hak atas informasi maka Pemerintah juga menetapkan undang-undang nomor 32 tahun 2002 tentang penyiaran.Dengan diberlakukannya undang-undang nomor 32 tahun 2002 tentang penyiaran pada tangal 28 desember 2002, dunia penyiaran Indonesia mengalami perubahan yang sangat berarti. Pertumbuhan penyiaran radio dan televisi baik di kota maupun di daerah semakin meningkat. Hal ini dikarenakan dengan diijinkannya penyelenggarann penyiaran radio dan televisi berjaringan atau lokal, sehinga terbuka peluang bagi masyarakat untuk berusaha dibidang penyiaran.

Berdasarkan Undang-undang nomor 32 Tahun 2002 tentang penyiaran dan Peraturan Pemerintah Nomor 52 Tahun 2005 tentang penyelenggaraan berdasarkan pancasila dan Undang-undang Dasar Negara Republik Indonesia Tahun 1945 dengan berdasarkan asas manfaat, adil, dan merata, kepastian hukum

\footnotetext{
${ }^{1}$ Dandrivanto Budhijanto, 2010, Hukum Telekomunikasi, Penyiaran, dan Teknologi Informasi Regulasi dan Konvergensi, Resfika Aditamma, Bandung, Hlm. 71.

${ }^{2}$ Ibid hlm.73
} 
e-ISSN : 2621-4105

keamanan, keberagaman, kemitraan, kebebasan dan tanggung jawab. Penyiaran di selenggarakan dengan tujuan untuk memperkukuh kesatuan nasional, terbentuknya watak dan jati diri bangsa yang beriman dan bertaqwa, mencerdaskan kehidupan bangsa, memajukan kesejahteraan umum, dalam rangka membangun masyarakat yang mandiri, demokrasi, adil dan sejahtera,serta menumbuhkan industri penyiaran indonesia.

Selain itu, penyiaran juga mempunyai fungsi kebudayaan dan ekonomi.Penyiaran sebagai penyalur informasi perannya semakin strategis terutama dalam megembangkan alam demokrasi di Negara Indonesia, penyiaran telah menjadi salah satu sarana berkomunikasi bagi masyarakat, lembaga penyiaran, dunia bisnis dan pemerintah. Pertumbuhan penyiaran televisi baik di kota maupun di daerah semakin meningkat. Hal ini dikarenakan dengan diijinkannya penyelenggaraan penyiaran Radio dan Televisi berjaringan atau lokal, sehingga terbuka peluang bagi masyarakat untuk berusaha di bidang penyiaran, khususnya yang begitu diminati yaitu penyiaran berlangganan TV kabel, oleh karena itu dibentuklah peraturan pemerintah Nomor 52 Tahun 2005 tentang Penyelenggaraan Penyiaran Lembaga Penyiaran Berlangganan yang didalamnya mengatur tentang pendirian dan perizinan. ${ }^{3}$

Perkembangan dunia informasi pada saat ini cukup pesat, seiring dengan hal tersebut kebutuhan masyarakat akan ketersediaan kesempatan mengakses informasi pun menjadi mengemuka. Hal ini kemudian melahirkan kebutuhan lain yang mengiringi kebutuhan infromasi yaitu kebutuhan masyarakat akan ketersediaan media yang tidak hanya memberikan manfaat edukatif namun juga memiliki manfaat dalam hal ini memberikan hiburan kepada masyarakat.

Sejak paruh abad ke-20, semenjak media tidak lagi bersifat konvensional (media cetak), telah dikembangkan bentuk media-media baru yang dengan tanpa memakan waktu yang lama kemudian menjadi primadona bagi masyarakat dunia

${ }^{3}$ Peraturan Pemerintah Nomor 52 Tahun 2005 tentang penyelenggaraan lembaga penyiaran berlangganan 
e-ISSN : 2621-4105

saat itu, diawali dengan lahirnya media audio (radio), dan disusul dengan lahirnya media audio/visual (televisi) pada beberapa paruh waktu setelahnya.

Sejak televisi ditemukan dan mulai dikembangkan dengan begitu cepat memberi dampak yang begitu signifikan terhadap pendirian stasiun televisi, jika Amerika disebut sebagai salah satu yang menjadi pelopornya maka hal ini tidaklah dapat disangkal kebenaraanya.

Hampir seluruh stasiun televisi diseluruh dunia berlomba-lomba membuat program dan menyajikan kepada seluruh khalayak diseluruh dunia. Disatu sisi, hal ini merupakan sebuah kemajuan yang sangat berarti dalam dunia informasi, dilain sisi hal yang demikian ini justru telah membuat masyarakat menjadi "keranjingan" untuk menonton siaran televisi. Dalam satu hari misalnya, ada sebagian kalangan masyarakat yang justru menghabiskan waktunnya hanya dengan menonton siaran televisi. Masyarakat Indonesia pada hari ini merupakan komunitas yang sangat haus akan informasi dan tidak ingin dikatakan sebagai orang yang ketinggalan jaman karena ketinggalan informasi

Siaran televisi sejak tahun 1998 mengawali kiprah layanannya disambut baik oleh beberapa kalangan masyarakat yang ingin mengoptimalkan hiburan melalui siaran televisi, mengingat saat itu produksi siaran-siaran lokal Indonesia masih sangat sedikit.

Penyelenggaraan penyiaran televisi berlangganan merupakan layanan jasa yang sudah menjadi warna gaya kehidupan di Indonesia. Kehadiran televisi berlangganan memberikan irama dalam menikmatiLembaga Penyiaran Televisi Berlangganan memberikan keragaman pada materi isi siaran yang ditawarkan kepada pelanggan, dikelompokkan ke dalam saluran-saluran siaran free-to-air baik lokal dan internasional, saluran siaran yang diproduksi sendiri (in-house production), saluran berbayar (pay channel), dan bahkan menawarkan saluransaluran ekslusif (exclusive channels) yang mempunyai nilai jual dan diferensiasi 
e-ISSN : 2621-4105

terhadap produk pesaing dengan membayar mahal suatu hak siar, contoh : "Hak Siar Liga Inggris 2017/2018 dan Hak Siar Piala Dunia 2018”.

Selain isi siaran menawarkan kualitas gambar juga jauh lebih baik dari siaran televisi biasa (terrestrial) dengan resolusi gambar Standard Definition dan saat ini telah masuk di era High Definition dan 3 Dimensi. Demikian juga dengan dekoder yang berguna untuk mengatur saluran televisi yang diterima, memeriksa hak akses pengguna, kemudian menghasilkan gambar, suara dan layanan lainnya telah menggunakan teknologi sistem kompresi MPEG-4 dari sebelumnya MPEG2.

Perubahan akan teknologi, gaya hidup, ekonomi, dan sosial di Indonesia memberikan implikasi akan bisnis penyiaran televisi berlangganan. Tahun 1988 hingga 2018 penyiaran televisi berlangganan sudah menjadi tidak asing di mata masyarakat di Indonesia. Tidak heran lembaga penyiaran penyedia jasa ini semakin banyak hadir dalam industri televisi berlangganan. Kemunculan Lembaga Penyiaran Televisi Berlangganan baru didasari oleh potensi pasar yang cukup besar dimana menurut CASBAA5 penetrasi pasar pelanggan televisi berlangganan terhadap jumlah rumah tangga yang mempunyai televisi (TV Homes) di Indonesia masih sangat rendah, yaitu 3,3\% dibanding dengan negara negara tetangga yang telah mencapai 30\% - 65\%. Pertumbuhan penetrasi televisi berlangganan di Indonesia 4 tahun kedepan sebesar 5,744,000 pelanggan atau bertumbuh hingga $13 \%$.

Lembaga Penyiaran Televisi Berlangganan rata-rata menggunakan platform teknologi berbasis satelit agar dapat memancarkan siaran ke seluruh pelosok Indonesia, mencakup wilayah lintas batas yang cukup luas dengan masyarakat yang terlalu heterogen sehingga perlu mengelompokkan pasar menjadi segmen-segmen pasar, lalu memilih dan menetapkan segmen pasar tertentu sebagai pasar sasaran (target market) dengan tujuan dapat mengembangkan produk yang tepat, menentukan saluran distribusi yang efektif dan cepat untuk 
e-ISSN : 2621-4105

penetrasi pasar, pengeluaran biaya promosi yang efisien serta mampu menyesuaikan harga bagi jasa yang ditawarkan ke pasar sasaran dengan tujuan menghasilkan keuntungan optimal dengan mengurangi resiko tetapi dapat memberikan manfaat yang tinggi ke pelanggan. Penggunaan Distributor sangat efektif sebagai saluran distribusi karena spesialisasi, pengalaman, mempunyai tenaga teknisi pemasangan (installer)dan jaringan pengecer (retailer) di area wilayah pemasaran dan penjualannya.

Saluran distribusi yang efektif dan cepat untuk penetrasi pasar yang dimaksud diatas dilakukan melalui kesepakatan yang dituangkan dalam perjanjian kerjasama Distributor untuk memasarkan dan mengelola jasa pelayanan televisi berlangganan satelit untuk suatu wilayah yang telah ditentukan dengan sistem retail berjaringan, memproses pendaftaran calon Pelanggan, menyediakan perangkat sesuai dengan spesifikasi yang ditentukan, menyediakan layanan purna jual kepada Pelanggan sesuai dengan Service Level Agreementdalam jangka waktu tertentu dengan mendapatkan imbalan komisi.

Perjanjian ini merupakan salah satu perjanjian yang mempunyai latar belakang ekonomi dan bisnis dimana ada dua pihak yang terkait di dalamnya yaitu pihak prinsipal (pihak yang mengangkat) sebagai pemilik dan penyediaan jasa pelayanan televisi berlangganan satelit direct-to-home dengan nama dagang Indovision dan pihak Distributor (pihak yang ditunjuk / diangkat).

Dalam pelaksanaan perjanjian kerjasama Distributor banyak ditemui penyimpangan-penyimpangan khususnya yang dilakukan oleh Distributor. Bentuk penyimpangan tersebut tampak pada kasus-kasus yang terjadi hampir di seluruh Distributor misalnya, dalam hal pembayaran bulanan iuran berlangganan pertama yang sudah dibayarkan pelanggan melalui Distributor atau Dealer dibawahnya tetapi tidak disetorkan ke rekening Indovision, pembayaran komisi oleh Distributor, memasarkan produk pesaing, tidak mendistribusikan perangkat dan 
e-ISSN : 2621-4105

layanan purna jual tidak sesuai service level agreement kepada Pelanggan yang akhirnya berdampak pada kerugian di Indovision.

Bentuk penyimpangan-penyimpangan diatas dapat menjadi gambaran bagi pengembangan Lembaga Penyiaran Berlangganan, khususnya Televisi Berlangganan di Indonesia, bila ada penyimpangan harus di cari tahu faktor apa yang menyebabkan penyimpangan tersebut hingga upaya dapat mencarikan solusinya dan pencegahan sebelum penyimpangan-penyimpangan tesebut terulang lagi di kemudian hari, maka dibutuhkan pemahaman dan pengetahuan tentang aturan hukumnya baik dalam menyusun perjanjian kerjasama Distributor dan faktor pendorong terjadinya penyimpangan pelaksanaan perjanjian kerjasama.

\section{B. PERMASALAHAN}

Berdasarkan latar belakang tersebut di atas dan untuk lebih terfokus dalam membahas tulisan ini sehingga mampu menguraikan pembahasan dengan tepat, maka disusun beberapa permasalahan. Adapun perumusan masalah dalam tesis ini adalah sebagai berikut:

1. Bagaimana perlindungan hukum terhadap pelanggan tv berbayar sesuai dengan Peraturan Pemerintah Nomor 52 Tahun 2005 ?

2. Bagaimana kendala, dan solusi atas perlindungan hukum terhadap pelannggan tv berbayar ditinjau dari Peraturan Pemerintah Nomor 52 Tahun 2005?

\section{PEMBAHASAN}

\section{Perlindungan Hukum Terhadap Konsumen Dalam Penggunaan Televisi Berbayar Berdasarkan Undang-undang Perlindungan Konsumen}

Penyiaran di Indonesia berkembang sangat pesat sekali, iklim usaha didunia penyiaran dinilai cukup menjanjikan karena penyiaran saat ini menjadi media yang paling dicari atau diandalkan oleh banyak orang untuk mencapai tujuannya, misalnya saja untuk promosi berbagai produk barang atau jasa, sarana penyampaian berita, bahkan sebagai sarana kampanye politik. Penyiaran dianggap sebagai sarana yang efektif karena 
Penghentian siaran televisi berlangganan secara sepihak oleh operator televisi berlangganan tentu saja sangat merugikan berbagai pihak, terlebih konsumen yang menjadi korban dalam penghentian siaran itu. Tindakan pelaku usaha dalam kasus ini adalah operator penyelenggara televisi berlangganan telah melanggar Undang-undang Perlindungan Konsumen, dalam Pasal 4 Undang-undang Perlindungan Konsumen ini dikatakan bahwa konsumen mempunyai hak untuk :

1. Hak atas kenyamanan, keamanan dan keselamatan dalam mengkonsumsi barang dan/atau jasa;

2. Hak untuk memilih barang dan/atau jasa serta mendapatkan barang dan/atau jasa tersebut sesuai dengan nilai tukar dan kondisi serta jaminan yang dijanjikan;

3. Hak atas informasi yang benar, jelas, dan jujur mengenai kondisi dan jaminan barang dan/atau jasa;

4. Hak untuk didengar pendapat dan keluhannya atas barang dan / atau jasa yang digunakan;

5. Hak untuk mendapatkan advokasi, perlindungan, dan upaya penyelesaian sengketa perlindungan konsumen secara patut;

6. Hak untuk mendapat pembinaan dan pendidikan konsumen;

7. Hak untuk diperlakukan atau dilayani secara benar dan jujur serta tidak diskriminatif;

8. Hak untuk mendapatkan kompensasi, ganti rugi dan/atau penggantian, apabila barang dan/atau jasa yang diterima tidak sesuai dengan perjanjian atau tidak sebagaimana mestinya;

9. Hak-hak yang diatur dalam ketentuan peraturan perundang-undangan lainnya.

Konsumen sebagai pengguna terakhir dari pemakaian barang atau jasa diharapkan untuk mengerti akan hak-hak yang dimilikinya, banyak konsumen 
yang tidak mengerti akan hak-hak yang dimilikinya, hal ini diakibatkan karena kurangnya informasi yang didapat oleh masyarakat tentang perlindungan konsumen.

Konsumen harus cerdas agar tidak dimanfaatkan oleh pelaku usaha yang tidak bertanggungjawab, sekarang memang ada prinsip tentang Caveat Venditor yaitu suatu adigium yang mengatakan bahwa pelaku usaha harus berhati-hati, karena jika pelaku usaha tidak berhati-hati maka konsumen dapat mengajukan gugatan terhadap pelanggaran yang dilakukan oleh pelaku usaha. Untuk mencapai tingkat dimana konsumen mengerti akan hak-haknya adalah dengan memberikan informasi serta pemahaman yang benar-benar kepada masyarakat tentang perlindungan konsumen.

Penghentian siaran yang dilakukan secara sepihak oleh suatu lembaga penyiaran berlangganan memang tidak dapat dibenarkan, baik jika dipandang dari sudut pandang hukum maupun dari sudut pandang etika, dari sudut pandang hukum jelas hal ini tidak dapat dibenarkan karena pengguna/pelanggan dari jasa penyiaran dengan pihak penyelenggara operator televisi berlangganan tersebut, tentunya sebelum terjadinya kesepakatan untuk penggunaan jasa siaran berlangganan antara penyelenggara dengan pelanggan telah terjadi perjanjian yang saling mengikat untuk kedua belah pihak, Di dalam Pasal 1320 KUHPerdata disebutkan bahwa untuk sahnya suatu perjanjian harus memenuhi 4 (empat) syarat yaitu :

1. Sepakat mereka yang mengikatkan dirinya;

2. Kecakapan untuk membuat suatu perikatan;

3. Suatu hal tertentu;

4. Suatu sebab yang halal.

Apabila di antara salah satu syarat tidak terpenuhi maka perjanjian tersebut dianggap tidak sah. Dalam Pasal 1337 KUHPerdata disebutkan bahwa suatu sebab adalah terlarang, apabila dilarang oleh undang-undang, atau 
apabila berlawanan dengan kesusilaan baik atau ketertiban umum. kemudian, dalam Pasal 1338 KUHPerdata tentang akibat suatu perjanjian disebutkan bahwa semua perjanjian yang dibuat secara sah berlaku sebagai undangundang bagi mereka yang membuatnya. Suatu perjanjian tidak dapat ditarik kembali kecuali dengan sepakat kedua belah pihak, atau karena selain alasanalasan yang oleh undang-undang dinyatakan cukup untuk itu. Suatu perjanjian harus dilaksanakan dengan itikad baik, jadi jelas apa yag dilakukan Astro terhadap pelanggannya telah melanggar isi perjanjian yang sebelumnya telah dibuat oleh kedua belah pihak.

Perbuatan ini tentunya menimbulkan kerugian bagi para pelanggannya, kerugian dapat berupa kerugian materiil dan kerugian immateriil, kerugian materiil adalah kerugian yang dapat dihitung atau diperkirakan jumlahnya karena bentuknya nyata dan dapat diperhitungkan dengan menggunakan buktibukti yang ada, sedangkan kerugian immateriil adalah kerugian yang sulit dihitung secara jelas tetapi hanya dapat diperkirakan saja. Perusahan TV berbayar telah melanggar hak konsumen sebagaimana yang diatur dalam Undang-undang Tentang Perlindungan Konsumen, konsumen harus mendapat informasi yang jelas tentang produk dan jasa, konsumen juga harus mendapatkan kepastian hukum tentang penggunaan produk dan jasa.

Selain kerugian materiil dan immateriil diatas, konsumen juga mengalami kerugian lain atas penghentian siaran secara sepihak tersebut, kerugian lain yang menimbulkan dampak negatif yaitu:

1. Dampak ekonomi;

Dampak ekonomi yaitu dampak yang baik secara langsung maupun tidak langsung berimbas kepada keadaan ekonomi seseorang, dalam hal ini adalah para pelanggan TV kabel telah mengalami kerugian secara ekonomi karena mereka telah membayar untuk dapat menyaksikan tayangan yang disediakan oleh TV kabel,tetapi pada kenyataannya mereka tidak 
mendapatkan hak sebagaimana mestinya, dan dari sudut ekonomi tentu saja mereka telah dirugikan oleh kejadian ini.

2. Dampak psikis;

Dampak psikilogis dari kejadian ini dialami oleh konsumen, misalnya saja konsumen mengalami trauma untuk menggunakan jasa televisi berlangganan karena kasus TV Indovision ini, terlebih hingga saat ini penyelesaian TV kabel ini belum benar-benar terselesaikan. Dampak psikologis ini benar-benar terasa karena konsumen benar-benar dikejutkan dengan pemutusan siaran secara sepihak yang dilakukan oleh TV kabel ini.

Konsumen mengalami kerugian yang tentunya menimbulkan dampak terhadap dirinya baik dampak terhadap mental atau psikologinya maupun dampak terhadap perekonomiannya, karena konsumen telah dirugikan oleh operator penyelenggara televisi berlangganan karena konsumen telah membayar biaya atau iuran yang telah ditetapkan oleh TV kabel untuk menikmati siaran TV kabel.

Konsumen di Indonesia saat ini sebenarnya sudah mendapatkan perlindungan hukum yang cukup memadai bagi konsumen, Undang-undang Perlindungan Konsumen sudah mengatur berbagai ketentuan bagi kegiatan yang menyangkut pelaku usaha dengan konsumen, bahkan sampai kepada pilihan terhadap penyelesaian sengketa jika memang terjadi sengketa antara konsumen dengan pelaku usaha, yaitu berdasarkan Pasal 45 ayat 2 Undangundang Perlindungan Konsumen yang menyatakan penyelesaian sengketa konsumen dapat ditempuh melalui pengadilan atau di luar pengadilan berdasarkan pilihan sukarela para pihak yang bersengketa. Para pihak yang bersengketa dapat memilih salah satu cara untuk menyelesaikan permasalahan mereka, jika dilihat dari ketentuan ini tentunya Undang-undang Perlindungan Konsumen sudah memberikan kebebasan bagi para pihak yang bersengketa. Bentuk dari penyelesaian sengketa konsumen diatas adalah dengan : 
1. Penyelesaian sengketa secara damai.

Tujuan dari penyelesaian sengketa secara damai ini tentunya untuk mencari jalan terbaik bagi para pihak yang bersengketa, keuntungan dari penyelesaian sengketa secara damai ini diharapkan dapat menjadi media bagi kedua belah pihak yang saling bersengketa agar dapat menemukan jalan terbaik yaitu kedua-duanya merasakan win-win solution, cara seperti ini juga sesuai dengan budaya Indonesia yaitu musyawarah untuk mufakat, selain itu juga cara penyelesaian diluar pengadilan ini mempunyai keuntungan lain yaitu :

a. Hemat waktu;

b. Hemat biaya;

c. Hubungan kedua belah pihak jadi lebih baik karena prinsip win-win solution;

d. Kedua belah pihak akan merasa bebas dalam menentukan syarat-syarat penyelesaian masalah;

e. Tidak berbelit-belit.

Penyelesaian sengketa konsumen secara damai juga belum tentu dapat menyelesaikan sengketa yang terjadi, berdasarkan Keputusan Menteri Perindustrian dan Perdagangan Nomor 350/MPP/kep/12/2002 sebagai berikut:

a. Konsiliasi

Pasal 1 angka 9 Kepmen diatas menjelaskan bahwa konsiliasi adalah "proses penyelesaian sengketa konsumen diluar pengadilan dengan perantaraan BPSK untuk mempertemukan pihak yang bersengketa, dan penyelesaiannya diserahkan kepada para pihak"

b. Mediasi

Penyelesaian sengketa secara mediasi berdasarkan pasal 1 angka 10 menjelaskan bahwa mediasi adalah proses penyelesaian sengketa konsumen 
di luar pengadilan dengan perantaraan BPSK sebagai penasehat dan penyelesaiannya diserahkan kepada para pihak.

c. Arbitrase

Berdasarkan Pasal 1 angka 11 arbitrase adalah proses penyelesaian sengketa konsumen di luar pengadilan yang dalam hal ini para pihak yang bersengketa menyerahkan sepenuhnya penyelesaian kepada BPSK, selanjutnya mengenai penyelesaian sengketa itu diatur dalam Undangundang Nomor 30 Tahun 1999 tentang Arbitrase dan Alternatif Penyelesaian Sengketa. Didalam Pasal 1 ayat (1) Undang-undang Nomor 30 Tahun 1999 ini berbunyi "Arbitrase adalah cara penyelesaian suatu sengketa perdata diluar peradilan umum yang didasarkan pada perjanjian arbitrase yang dibuat secara tertulis oleh para pihak yang bersengketa.

2. Penyelesaian sengketa melalui lembaga atau instansi yang berwenang Sengketa konsumen dapat juga diselesaikan melalui lembaga atau instansi berwenang yaitu Pengadilan Negeri (PN), menurut Subekti dalam hukum menganut suatu asas orang tidak boleh menjadi hakim sendiri, apabila penyelesaian sengketa yang dipilih adalah secara litigasi, maka harus diperhatikan ketentuan hukum acara perdata yang berlaku di Indonesia, sesuai ketentuan hukum acara perdatanya, maka suatu perbuatan melawan hukum harus dibuktikan melalui proses pemeriksaan di lembaga peradilan mulai dari tingkat pertama (Pengadilan Negeri) sampai tingkat akhir (Pengadilan Tinggi atau mungkin Mahkamah Agung) dengan syarat adanya putusan hakim yang telah memiliki kekuatan hukum yang tetap dan pasti (inkracht van gewijsde).

\section{Tindakan Hukum Terhadap Operator Televisi Berlangganan Atas Penghentian Siaran Secara Sepihak Terhadap Konsumennya.}

Penyiaran menurut Undang-undang Tentang Penyiaran dibagi atas 4 (empat) jenis siaran, yang salah satunya adalah penyiaran berlangganan, yaitu suatu penyiaran yang diperuntukan hanya kepada mereka yang berlangganan saja, 
e-ISSN : 2621-4105

penyiaran berlangganan di Indonesia cukup banyak peminatnya, hal ini dikarenakan televisi berlangganan memeliki kelebihan dibandingkan dengan sistem televisi lainnya, misalnya pilihan channel yang beranekaragam yang bukan saja dari dalam negeri tetapi juga channel-channel top dunia.

Permasalahan yang timbul adalah ketika ada operator televisi berlangganan di Indonesia yaitu Indovison tv melakukan tindakan yang merugikan konsumennya dengan melakukan penambahan biaya untuk program liga inggris yang tidak pernah ada kesepakatan dari pihak pelanggan. Awalnya pihak Indovision berjanji untuk mengembalikan dan mengganti kerugian konsumennya, namun pada kenyataannya hingga saat ini belum ada tindakan penggantian kerugian yang diterima oleh konsumen.

Berdasarkan Pasal 4 Undang-undang Perlindungan Konsumen menyatakan bahwa:

1. Hak atas kenyamanan, keamanan, dan keselamatan dalam mengkonsumsi barang dan/atau jasa;

2. Hak untuk memilih barang dan/atau jasa serta mendapatkan barang dan/atau jasa tersebut sesuai dengan nilai tukar dan kondisi serta jaminan yang dijanjikan;

3. Hak atas informasi yang benar, jelas, dan jujur mengenai kondisi dan jaminan barang dan/atau jasa;

4. Hak untuk didengar pendapat dan keluhannya atas barang dan/atau jasa yang digunakan;

5. Hak untuk mendapatkan advokasi, perlindungan, dan upaya penyelesaian sengketa perlindungan konsumen secara patut;

6. Hak untuk mendapatkan advokasi, perlindungan, dan upaya penyelesaian sengketa perlindungan konsumen secara patut;

7. Hak untuk mendapat pembinaan dan pendidikan konsumen;

8. Hak untuk diperlakukan atau dilayani secara benar dan jujur serta tidak diskriminatif;

9. Hak-hak yang diatur dalam ketentuan peraturan perundang-undangan lainnya.

Penyiaran merupakan wilayah atau ladang yang sangat menggoda bagi pihak pemerintah maupun swasta karena penyiaran mempunyai keunggulan tersendiri 
e-ISSN : 2621-4105

yaitu mempunyai potensi ekonomi yang besar dan juga sebagai sarana politik yang baik untuk ditujukan kepada masyarakat karena Radio dan televisi sebagai sarana komunikasi massa elektronik memiliki pengaruh besar dalam membentuk pendapat masyarakat, sikap dan perilaku manusia.

Penyiaran merupakan salah satu bidang yang paling berpengaruh dalam kehidupan manusia. Penyiaran berdasarkan tujuan penyelenggaraannya menurut Undang-undang Penyiaran diharapkan dapat memperkukuh integrasi nasional, terbinanya watak dan jati diri bangsa yang beriman dan bertaqwa, mencerdaskan kehidupan bangsa, memajukan kesejahteraan umum, dalam rangka membangun masyarakat yang mandiri, demokratis adil dan sejahtera, serta menumbuhkan industri penyiaran Indonesia. Tujuan dari penyiaran ini diharapkan dapat tercapai dengan baik akan tetapi dalam penyelenggaraannya terdapat masalah-masalah yang dapat membuat tujuan dari penyiaran ini tidak tercapai, untuk mencegah halhal yang tidak diinginkan dalam proses penyelenggaraan penyiaran ini diperlukan sanksi-sanksi untuk memberi efek jera bagi para penyelenggara penyiaran agar tidak melakukan hal-hal yang bertentangan dengan peraturan perundangundangan yang ada, dari berbagai sanksi yang ada terhadap penyelenggara penyiaran salah satunya adalah pencabutan izin penyiaran. Lembaga penyiaran akan dicabut izinnya jika melihat ketentuan berdasarkan Pasal 34 Undang-undang Penyiaran Berdasarkan Pasal 55 ayat (1) dinyatakan bahwa setiap orang yang melanggar ketentuan sebagaimana yang dimaksud dalam Pasal yang salah satunya terdapat Pasal 34 ayat (5) akan dikenakan sanksi administratif yang diatur dalam Pasal 55 ayat (2) yaitu :

Sanksi administratif sebagaimana dimaksud ayat (1) dapat berupa :

a. Teguran tertulis;

b. Penghentian sementara mata acara yang bermasalah setelah melalui tahap tertentu;

c. Pembatasan durasi dan waktu siaran;

d. Denda administratif;

e. Pembekuan kegiatan siaran untuk waktu tertentu; 
e-ISSN : 2621-4105

f. Tidak diberi perpanjangan izin penyelenggaraan penyiaran;

g. Pencabutan izin penyelenggaraan penyiaran.

Dari ketentuan diatas menjadi alasan KPI untuk melakukan pencabutan izin penyiaran Indovison tv. Sanksi administratif yang diberikan oleh KPI kepada pihak Indovison tv adalah pencabutan izin penyelenggaraan penyiaran yang menyebabkan penghentian siaran televisi berlangganan ini. Karena kejadian ini aka proses penyiaran yang dilakukan oleh Indovison tv terhadap pelanggannya diberhentikan, tentu para konsumen merasa sangat dirugikan atas perbuatan Indovison tv ini, berdasarkan kejadian ini maka konsumen dapat melakukan tindakan hukum.

Pelaku usaha telah melanggar hak-hak yang dimiliki oleh konsumen karena konsumen tidak mendapatkan hak yang seharusnya di dapat. Pelaku usaha berdasarkan Pasal 7 Undang-undang Perlindungan Konsumen mempunyai kewajiban untuk :

1. Beritikad baik dalam melakukan kegiatan usahanya;

2. Memberikan informasi yang benar, jelas dan jujur mengenai kondisi dan jaminan barang dan/atau jasa serta memberi penjelasan penggunaan, perbaikan dan pemeliharaan;

3. Memperlakukan atau melayani konsumen secara benar dan jujur serta tidak diskriminatif;

4. Memberi kesempatan kepada konsumen untuk menguji, dan/atau mencoba barang dan/atau jasa tertentu serta memberi jaminan dan/atau garansi atas barang yang dibuat dan/atau yang diperdagangkan;

5. Memberi kompensasi, ganti rugi dan/atau penggantian atas kerugian akibat penggunaan, pemakaian dan pemanfaatan barang dan/atau jasa yang diperdagangkan;

6. Memberi kompensasi, ganti rugi dan/atau penggantian apabila barang dan/atau jasa yang diterima atau dimanfaatkan tidak sesuai dengan perjanjian.

Undang-undang Perlindungan Konsumen khususnya dalam Pasal 7 huruf f mengatur mengenai kewajiban pelaku usaha yaitu tentang pemberian kompensasi 
e-ISSN : 2621-4105

atau ganti kerugian karena barang atau jasa yang diterima atau yang dimanfaatkan tidak sesuai dengan perjanjian.

Penggantian kerugian, dapat dituntut menurut undang-undang berupa "kosten, schaden en interessen" yang dimaksudkan kerugian yang dapat dimintakan penggantian itu, tidak hanya biaya-biaya yang sungguh-sungguh telah dikeluarkan (kosten), atau kerugian yang sungguh-sungguh menimpa harta benda si berpiutang (schaden), tetapi juga yang berupa kehilangan keuntungan (interessen) yaitu keuntungan yang akan didapat seandainya si berhutang tidak lalai (winstderving) ${ }^{4}$.

Dalam Pasal 19 ayat (2) Undang-undang Perlindungan Konsumen dinyatakan bahwa pelaku usaha bertanggungjawab untuk memberikan ganti kerugian akibat kesalahannya, akan tetapi dalam kasus Astro ini pelaku usaha tidak mengganti kerugian kepada konsumennya, padahal jelas bahwa konsumen telah dirugikan akibat ulah pelaku usaha ini. Untuk kasus ganti rugi Astro ini di Indonesia telah diatur dalam Pasal 19 Undang-undang Perlindungan Konsumen dan untuk sanksi administratif bagi pelaku usaha yang mengabaikan Pasal 19 terdapat dalam Pasal 60 ayat (1) Undang-undang Perlindungan Konsumen ini. Oleh karena itu diharapkan adanya kerjasama dari berbagai pihak untuk menyelsaikan masalahmasalah perlidungan konsumen ini, harus ada kerja sama dari pelaku usaha, konsumen dan juga tentunya pemerintah.

Konsumen sebagai pengguna terakhir dari suatu barang/jasa harus dilindungi oleh hukum, tentu para pelaku usaha juga tidak boleh sewenangwenang terhadap konsumennya. Untuk melindungi konsumen dari perbuatanperbuatan yang tidak baik dari pelaku usaha pemerintah wajib memikirkan berbagai kebijakan untuk masyarakat sebagai konsumen agar tidak terjadi sengketa konsumen. Suatu sengketa terjadi apabila terdapat perbedaan pandangan atau pendapat dari suatu pihak tertentu mengenai suatu hal tertentu pula. Menurut penulis sengketa konsumen adalah sengketa yang terjadi antara konsumen sebagai pengguna barang atau jasa dengan pelaku usaha mengenai ketidaksesuaian antara

\footnotetext{
${ }^{4}$ Subekti. Op.Cit.hlm 148.
} 
barang atau jasa yang diperdagangkan. Menurut Undang-undang Perlindungan Konsumen pasal 45 ayat (1) menyatakan setiap konsumen yang dirugikan bisa menggugat pelaku usaha melalui lembaga yang bertugas menyelesaikan sengketa antara konsumen dengan pelaku usaha atau melalui peradilan yang berada dilingkungan peradilan umum. Konsumen dapat melakukan gugatan terhadap pelaku usaha karena kedudukan pelaku usaha dengan konsumen itu sama dimata hukum. Berdasarkan bunyi dari Pasal 46 Undang-undang Perlindungan Konsumen adalah:

1. Seorang konsumen yang dirugikan atau ahli waris yang bersangkutan;

2. Sekelompok konsumen yang mempunyai kepentingan yang sama;

3. Lembaga perlindungan konsumen swadaya masyarakat yang memenui syarat, yaitu berbentuk badan hukum atau yayasan, yang dalam anggaran dasarnya menyebutkan dengan tegas bahwa tujuan didirikannya organisasi tersebut adalah untuk kepentingan perlindungan konsumen dan telah melaksanakan kegiatan sesuai dengan anggaran dasarnya.

4. Pemerintah dan/atau instansi terkait jika barang dan/atau jasa yang dikonsumsi atau dimanfaatkan mengakibatkan kerugian materi yang besar dan/atau korban yang tidak sedikit.

Menurut Satjipto Rahardjo ${ }^{5}$ pembicaraan mengenai bekerjanya hukum dalam hubungan dengan proses peradilan secara konvensional melibatkan pembicaraan tentang kekuasaan kehakiman, prosedur berperkara dan sebagainya. Pertama didahului dengan pendaftaran surat gugatan di kepaniteraan perkara perdata di pengadilan negeri. Surat gugatan harus sudah dipersiapkan terlebih dahulu secara teliti dan cermat, berdasarakan Pasal 45 ayat (1) Undang-undang Perlindungan Konsumen menyatakan bahwa ;

1. Setiap konsumen yang dirugikan dapat menggugat pelaku usaha melalui lembaga yang bertugas menyelesaikan sengketa antara konsumen dan pelaku usaha atau melalui peradilan yang berada di lingkungan peradilan umum.

2. Penyelesaian sengketa konsumen dapat ditempuh melalui pengadilan atau di luar pengadilan berdasarkan pilihan sukarela para pihak yang bersengketa.

3. Penyelesaian sengketa di luar pengadilan sebagaimana dimaksud pada ayat (2) tidak menghilangkan tanggung jawab pidana sebagaimana diatur dalam Undang-undang.

4. Apabila telah dipilih upaya penyelesaian sengketa konsumen di luar pengadilan, gugatan melalui pengadilan hanya dapat ditempuh apabila upaya

\footnotetext{
${ }^{5}$ Sajipto Raharjo,permasalahan hukum Indonesia,bandung,PT Citra Aditya Bakti,1987
} 
tersebut dinyatakan tidak berhasil oleh salah satu pihak atau oleh para pihak yang, bersengketa.

Berdasarkan Pasal 46 Undang-undang Perlindungan Konsumen menyatakan pihak yang dapat melakukan gugatan konsumen adalah ${ }^{6}$ :

1. Seorang konsumen yang dirugikan atau ahli waris yang bersangkutan;

2. Sekelompok konsumen yang mempunyai kepentinyan yang sama;

3. Lembaga perlindungan konsumen swadaya masyarakat yang memenuhi syarat, yaitu berbentuk badan hukum atau yayasan, yang dalam anggaran dasarnya menyebutkan dengan tegas bahwa tujuan didirikannya organisasi tersebut adalah untuk kepentingan perlindungan konsumen dan telah melaksanakan kegiatan sesuai dengan anggaran dasarnya;

4. Pemerintah dan/atau instansi terkait apabila barang dan/atau jasa yang dikonsumsi atau dimanfaatkan mengakibatkan kerugian materi yang besar dan/atau korban yang tidak sedikit.

Penyelesaian sengketa konsumen melalui pengadilan ini biasanya terjadi jika keinginan masing-masing kedua belah pihak yang bersengketa tidak tercapai, konsumen dapat mengajukan gugatan ke pengadilan.

Proses beracara dalam sengketa konsumen, sengketa konsumen akan terjadi apabila terjadinya pelanggaran hak-hak konsumen dan tidak terpenuhinya kewajiban pelaku usaha. Banyak cara dalam penyelesaian sengketa konsumen ini. Biasanya dalam kehidupan sehari-hari sengketa konsumen akan melibatkan pihak konsumen yang melibatkan banyak orang, karena sengketa ini muncul karena ketidaksesuaian produk baik barang maupun jasa, dimana produk ini akan dikonsumsi lebih dari satu orang, meski demikian tidak menutup kemungkinan sengketa ini hanya melibatkan perseorangan. Cara yang dapat ditempuh dalam beracara sengketa konsumen :

1. Small Claim, adalah jenis gugatan yang dapat dilakukan oleh konsumen, sekalipun dilihat secara ekonomis nilai gugatannya sangat kecil. Ada tiga alasan mengapa small claim diijinkan dalam penyelesaian sengketa konsumen:

a. Kepentingan dari pihak penggugat tidak dapat diukur semata karena nilai uang kerugiannya,

b. Keyakinan bahwa pintu keadilan terbuka bagi siapa saja,

c. Untuk menjaga integritas badan-badan peradilan.

\footnotetext{
${ }^{6}$ UU No 8 tahun 1999 Tentang Perlindungan Konsumen
} 
2. Class Action, adalah gugatan konsumen dimana korbannya lebih dari satu orang atau gugatan yang dilakukan oleh sekelompok orang. Gugatan kelompok ini berdasarkan Peraturan Mahkamah Agung No. 1 tahun 2002 dikenal dengan “gugatan perwakilan kelompok". Dalam Undang-undang Perlindungan Konsumen gugatan kelompok ini diatur dalam pasal 46 ayat 1 (b).

Dalam Class Action wajib memenuhi empat syarat yang ditetapkan dalam pasal 23 US Federal Of Civil Procedure:

a. Numerosity, jumlah penggugat harus cukup banyak

b. Commonality, adanya kesamaan soal hukum dan fakta antara pihak yang diwakili dan pihak yang mewakili

C. Typicality, adanya kesamaan jenis tuntutan hukum dan dasar pembelaan yang digunakan antara anggota yang diwakili dan yang mewakili

d. Adequacy of Representation, adanya kemampuan kelas yang mewakili dalam mewakili pihak yang diwakili

3. Legal Standing, adalah gugatan yang dilakukan sekelompok konsumen dengan menunjuk pihak LSM yang dalam kegiatannya berkonsentrasi pada kegiatan konsumen untuk mewakili kepentingan konsumen atau dikenal dengan Hak Gugat LSM. LSM tersebut haruslah berbadan hukum atau yayasan.

Konsumen yang menggunakan televisi berlangganan Indovision sebagai pihak yang dirugikan berhak melakukan gugatan yang mengacu pada ketentuan Pasal 45 ayat (1) Undang-undang Perlindungan Konsumen yang menyatakan bahwa setiap konsumen yang dirugikan dapat menggugat pelaku usaha melalui lembaga yang bertugas menyelesaikan sengketa antara konsumen dan pelaku usaha atau melalui peradilan yang berada dilingkungan peradilan umum, dan juga berdasarkan ketentuan yang diatur didalam Pasal 1365 Kitab Undang-Undang Hukum Perdata yang menyatakan bahwa setiap perbuatan melanggar hukum, yang membawa kerugian kepada orang lain, mewajibkan orang yang karena salahnya menerbitkan kerugian itu, mengganti kerugian tersebut. 
e-ISSN : 2621-4105

Ganti kerugian menurut Undang-undang Perlindungan Konsumen dapat didasarkan atas 2 (dua) alasan mengenai ganti kerugian yang dapat dimintakan oleh konsumen kepada pelaku usaha, lingkup tanggung jawab pembayaran ganti kerugian, secara umum tuntutan ganti kerugian atas kerugian yang dialami oleh konsumen sebagai akibat penggunaan produk, baik yang berupa kerugian meteri, fisik maupun jiwa, secara garis besarnya hanya ada dua kategori yaitu:

1. Tuntutan berdasarkan wanprestasi

Tuntutan berdasarkan wanprestasi berarti antara produsen dengan konsumen terikat suatu perjanjian, yang mana dalam hal ini produsen tidak dapat memenuhi prestasi sebagaimana yang telah diperjanjikan sebelumnya.

2. Tuntutan berdasarkan suatu perbuatan melawan hukum.

Jika tuntutan didasarkan kepada suatu perbuatan melawan hukum maka harus dipenuhi unsur-unsur:

a. Adanya perbuatan melanggar hukum,

b. Adanya kerugian,

C. Adanya kausalitas antara perbuatan melanggar hukum dengan kerugian,

d. Adanya kesalahan.

Selanjutnya pada proses pembuktian, harus dapat dibuktikan unsur-unsur yang menunjukkan adanya perbuatan melawan hukum ini melalui alat-alat bukti yang diakui dalam Pasal 164 HIR (Het Herziene Indonesisch Reglement), baik bukti secara tertulis (misalnya print out dokumen-dokumen yang berhubungan dengan penghentian siaran ini), saksi-saksi, sebagaimana diatur dalam Pasal 153 HIR, persangkaan, pengakuan dan sumpah.

Dalam proses pembuktian di pengadilan konsumen harus dapat membuktikan bahwa konsumen memang telah benar-benar di rugikan oleh tindakan pelaku usaha dalam hal ini oleh Indovison tv sebagai pemegang merek televisi berlangganan.

\section{E. PENUTUP}


Perlindungan Hukum Terhadap Pelanggan Tv Berbayar Ditinjau Dari Peraturan Pemerintah Nomor

52 Tahun 2005 Tentang Penyelenggaraan Lembaga Penyiaran

Berlangganan Melalui Satelit, Kabel Dan Teresterial

Rini Sulistyowati

e-ISSN : 2621-4105

Perlindungan hukum terhadap konsumen yang mengalami kerugian dalam perjanjian jasa penyiaran Televisi berbayar dibagi dalam dua bentuk yaitu perlindungan hukum secara preventif dan perlindungan hukum secara represif. Disamping itu juga ada tanggung jawab hukum dari pelaku usaha jasa penyiaran TV kabel jika konsumen merasa dirugikan. Hal tersebut sesuai dengan ketentuan yang diatur didalam Undang-Undang Nomor 8 Tahun 1999 Tentang Perlindungan Konsumen baik secara pidana maupun perdata. Dalam penyimpangan dapat menjadi gambaran kerugian yang tentunya menimbulkan dampak terhadap konsumen baik dampak terhadap mental atau psikologinya maupun dampak terhadap perekonomiannya, karena konsumen telah dirugikan oleh operator penyelenggara televisi berlangganan yang membayar biaya atau iuran yang telah ditetapkan oleh TV kabel untuk menikmati siaran TV kabel.

Upaya penyelesaian yang dapat dilakukan oleh konsumen sebagai pengguna jasa penyiaran Televisi Kabel,atas kerugian yang dialaminya dapat dilakukan melalui litigasi dan melalui non litigasi hal tersebut sesuai dengan Pasal 23 jo Pasal 45 Undang-Undang Nomor 8 Tahun 1999 Tentang Perlindungan Konsumen dengan memperhatikan jangka waktu yang telah ditentukan.

\section{DAFTAR PUSTAKA}

\section{BUKU}

Dandrivanto Budhijanto, 2010, Hukum Telekomunikasi, Penyiaran, dan Teknologi Informasi Regulasi dan Konvergensi, Resfika Aditamma, Bandung

Sajipta Raharjo, 1987, Permasalahan hukum Indonesia, PT Citra Aditya Bakti, bandung.

\section{UNDANG-UNDANG}

UU No 8 tahun 1999 Tentang Perlindungan Konsumen 
Perlindungan Hukum Terhadap Pelanggan Tv Berbayar Ditinjau Dari Peraturan Pemerintah Nomor 52 Tahun 2005 Tentang Penyelenggaraan Lembaga Penyiaran Berlangganan Melalui Satelit, Kabel Dan Teresterial Rini Sulistyowati

e-ISSN : 2621-4105

Peraturan Pemerintah Nomor 52 Tahun 2005 tentang penyelenggaraan lembaga penyiaran berlangganan

Departemen Perhubungan, Keputusan Menteri Perhubungan Tentang Penyelenggaraan Jasa Telekomunikasi, Kepmen Perhubungan Nomor KM 21 Tahun 2001, ps.3 huruf c.

\section{INTERNET}

http://www.Pikiran_Rakyat.co.id M.Z. Al-Faqih, Perjalanan Regulasi Penyiaran di Indonesia. 